\title{
SKIN REACTIONS TO NUCLEOPROTEIN OF STREPTOCOCCUS SCARLATINAE IN PATIENTS WITH RHEUMATOID ARTHRITIS AND RHEUMATIC FEVER
}

\author{
BY WALTER K. MYERS, CHESTER S. KEEFER AND \\ THEODORE W. OPPEL \\ (From the Thorndike Memorial Laboratory, Second and Fourth Medical Services (Harvard), \\ Boston City Hospital and the Department of Medicine, Harvard Medical School, \\ Boston)
}

(Received for publication, October 11, 1932)

The skin reactions to various products of the hemolytic streptococci have been studied by a number of observers, and attempts have been made to correlate the results of such tests with various clinical manifestations of streptococcal infection. In the present investigation the skin reactions to varying amounts of nucleoprotein derived from a strain of Streptococcus scarlatinae were studied in 207 miscellaneous hospital patients, and in sixty patients with acute rheumatic fever and rheumatoid arthritis, in an endeavor to determine whether more patients in this latter group reacted to the streptococcal "nucleoprotein" or to smaller amounts of the material than patients with other diseases. At the same time the blood serum of these patients was examined for the presence of streptococcal agglutinins.

\section{METHODS}

A strain of Streptococcus hemolyticus derived from a case of scarlet fever $\left(\mathrm{SD}_{1}\right)$ was grown in veal infusion broth, buffered with 0.2 per cent anhydrous disodium phosphate, and adjusted to $\mathrm{pH}$ 7.2. The organisms obtained from an eighteen to twenty-four hour growth in ten liters of broth were packed by centrifuging, and then washed three times with sterile physiological salt solution. The organisms were then dried in vacuo at room temperature. The dry mass of organisms was ground in a ball mill for eight days until a very fine powder was obtained. This powder was suspended in $333 \mathrm{cc}$. of N/100 sodium hydroxide and placed in the icebox for twenty-four hours, during which time it was shaken frequently. The material was then centrifuged several hours and the supernatant fluid withdrawn. This was treated in the cold with the minimal amount of 10 per cent acetic acid necessary to cause maximal precipitation. The precipitate was redissolved in the N/100 sodium hydroxide and reprecipitated with 10 per cent acetic acid. This procedure was repeated on two occasions. The final precipitate was dialyzed in collodion sacs against distilled water for twenty-four hours, and then 
washed in acetone and ether. The dry powder was kept in a vacuum desiccator. The powdered "nucleoprotein" was dissolved in normal saline solution and diluted so that $0.1 \mathrm{cc}$. contained $0.01 \mathrm{mgm}$. of "nucleoprotein." This method is essentially the same as that described by Lancefield (1). Three dilutions were used in making all of the tests, each containing $0.01 \mathrm{mgm}$., $0.001 \mathrm{mgm}$., and $0.0001 \mathrm{mgm}$. of nucleoprotein respectively. Normal saline was used as a control. All the tests were made by injecting the material intradermally on the extensor surface of the forearm. The size of the wheal was measured immediately, and again twenty-four hours later. Reactions of less than $1 \mathrm{~cm}$. in diameter were regarded as negative, and reactions of $1 \mathrm{~cm}$. or above were considered positive.

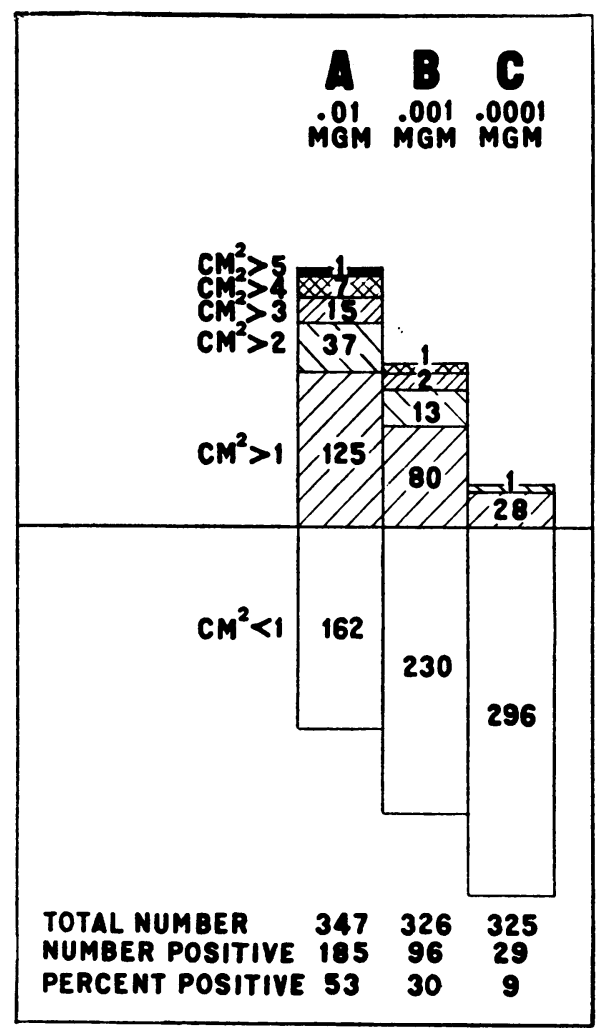

Fig. 1. The Results of Skin Reactions to Varying Amounts of STREPTOCOCCAL NUCLEOPROTEIN

The columns $\mathrm{A}, \mathrm{B}$, and $\mathrm{C}$ represent the number and size of the reactions in patients following $0.01 \mathrm{mgm} ., 0.001 \mathrm{mgm}$., and $0.0001 \mathrm{mgm}$. respectively.

All of the patients were examined while resident in the Boston City Hospital, and their ages varied from ten to seventy-five years. The 
agglutination tests were done in accordance with the technique outlined in a previous communication.

\section{RESULTS}

The results of 998 tests done on 325 patients are charted in Figure 1. The greatest number of cases reacted to $0.01 \mathrm{mgm}$. of the material, and the sizes of the positive reactions varied from 1 to $5 \mathrm{~cm}$. in diameter. It is observed that the number of positive reactions in the whole group depended to some extent upon the amount of material used. It was necessary, however, to determine whether or not the reactions observed were more common, and more striking, in special groups of cases. For purposes of more detailed study the patients were divided into four groups (Table 1).

TABLE 1

Results of skin tests

\begin{tabular}{|c|c|c|c|c|c|c|c|c|}
\hline \multirow[t]{2}{*}{ Group } & \multirow[t]{2}{*}{ Disease } & \multirow{2}{*}{$\begin{array}{l}\text { Total } \\
\text { num- } \\
\text { ber } \\
\text { of } \\
\text { cases }\end{array}$} & \multicolumn{2}{|c|}{$\begin{array}{c}\text { Positive } \\
\text { reactions } \\
\text { with .01 } \\
\text { mgm. } \\
\text { nucleo- } \\
\text { protein }\end{array}$} & \multicolumn{2}{|c|}{$\begin{array}{c}\text { Positive } \\
\text { reactions } \\
\text { with .001 } \\
\text { mgm. } \\
\text { nucleo- } \\
\text { protein }\end{array}$} & \multicolumn{2}{|c|}{$\begin{array}{c}\text { Positive } \\
\text { reactions } \\
\text { with .0001 } \\
\text { mgm. } \\
\text { nucleo- } \\
\text { protein }\end{array}$} \\
\hline & & & $\underset{\text { ber }}{\text { num- }}$ & $\begin{array}{c}\text { per } \\
\text { cent }\end{array}$ & num- & $\begin{array}{c}\text { per } \\
\text { cent }\end{array}$ & $\underset{\text { ber }}{\text { num- }}$ & $\begin{array}{c}\text { per } \\
\text { cent }\end{array}$ \\
\hline $\begin{array}{l}1 \\
2 \\
3 \\
4\end{array}$ & 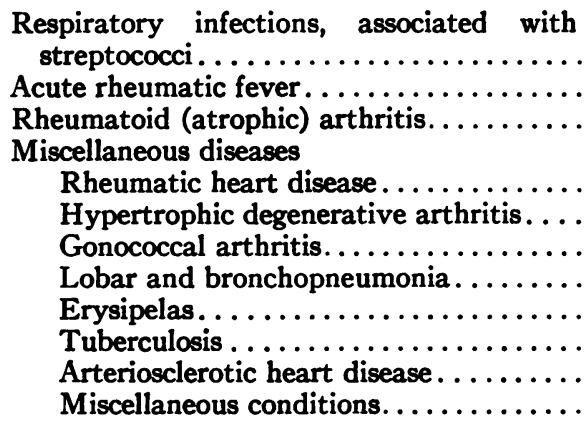 & $\begin{array}{l}20 \\
40 \\
20 \\
\\
26 \\
23 \\
12 \\
18 \\
15 \\
16 \\
24 \\
73\end{array}$ & $\begin{array}{r}19 \\
31 \\
14 \\
\\
14 \\
7 \\
5 \\
6 \\
8 \\
5 \\
10 \\
27\end{array}$ & \begin{tabular}{|l}
95 \\
77 \\
70 \\
\\
53 \\
30 \\
41 \\
33 \\
53 \\
31 \\
42 \\
36
\end{tabular} & $\begin{array}{r}11 \\
26 \\
9 \\
8 \\
2 \\
2 \\
1 \\
5 \\
1 \\
2 \\
12\end{array}$ & $\begin{array}{r}55 \\
65 \\
45 \\
\\
30 \\
6 \\
17 \\
6 \\
33 \\
6 \\
8 \\
16\end{array}$ & $\begin{array}{l}5 \\
8 \\
2 \\
2 \\
0 \\
0 \\
1 \\
0 \\
0 \\
0 \\
5\end{array}$ & \begin{tabular}{|r}
25 \\
20 \\
10 \\
7 \\
0 \\
0 \\
5.5 \\
0 \\
0 \\
0 \\
7
\end{tabular} \\
\hline
\end{tabular}

The 163 individuals with a miscellany of conditions were affected with such diseases as gonococcal arthritis, bronchopneumonia, lobar pneumonia, tuberculosis, diabetes, syphilis, duodenal ulcer, hyperthyroidism, alcoholic neuritis, chronic nephritis and carcinoma. Of these patients 44 per cent showed positive reactions to $0.01 \mathrm{mgm}$. or less of the nucleoprotein but in only 12 per cent was the reaction over $2 \mathrm{~cm}$. in diameter.

Of the patients with acute respiratory infections due to streptococcal infections, such as streptococcal sinusitis and acute follicular tonsillitis, 95 per cent showed positive reactions, and in 36 per cent the reaction was greater than $2 \mathrm{~cm}$. in diameter.

In patients with acute rheumatic fever 77 per cent showed positive 
reactions, and in 32 per cent the reaction was greater than $2 \mathrm{~cm}$. Seventy per cent of the patients with rheumatoid arthritis reacted positively, and in 30 per cent the reaction was greater than $2 \mathrm{~cm}$. From these observatious it is evident that the patients comprising the last three groups reacted positively more of ten, and with more intense reactions, than the group with a miscellany of conditions.

In order to determine whether the patients with respiratory infections, acute rheumatic fever, and rheumatoid arthritis reacted to smaller amounts of the streptococcal nucleoprotein as well as reacting more intensely, Figures 2 and 3 were constructed.

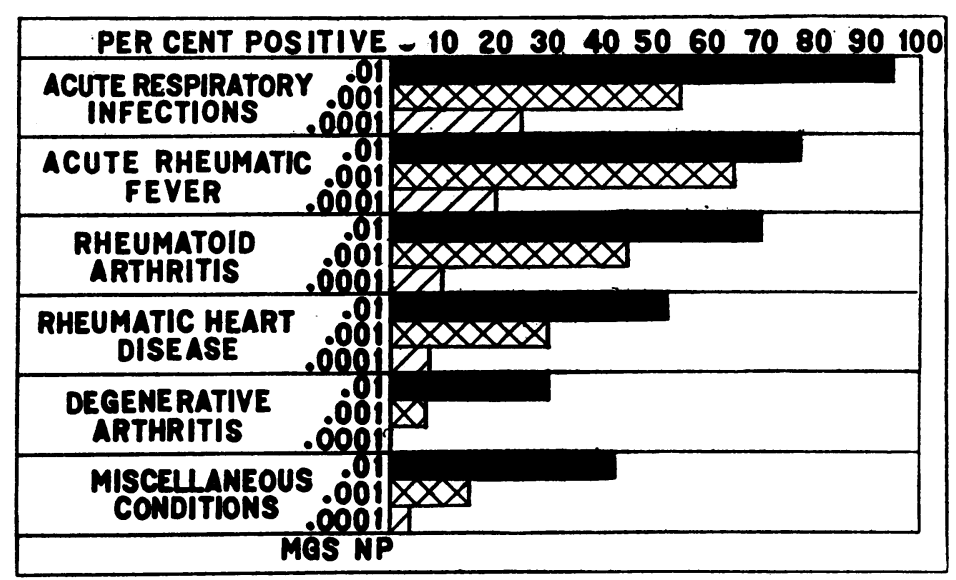

Fig. 2. The Positive Reactions to Varying Amounts of Nucleoprotein in Different Disease Conditions

It is seen that the patients with acute respiratory infections associated with streptococci $(C)$, acute rheumatic fever $(B)$, and rheumatoid (atrophic) arthritis $(A)$, not only showed a higher percentage of positive reactions, but they also showed positive reactions more of ten to smaller amounts of the material, than the patients with a miscellany of conditions.

Despite these observations, it was not possible to show any constant relationship between the size or intensity of the reaction, and the patient's clinical condition. Many patients, who were acutely ill, showed very slight reactions, whereas other patients, who were not acutely ill, showed marked reactions.

The skin reactions of the patients with acute rheumatic fever and rheumatoid arthritis, persisted in most cases in the same degree and intensity for months. Twenty-one of the patients were retested at intervals of from one to six months, and it may be seen from Table 2 that in most cases the reactions were of the same intensity during the period of observation. This was true no matter whether improvement 
took place or not, or whether cultures of the throat and tonsils showed hemolytic streptococci.

In nineteen of the patients, repeated examinations of the pharynx and tonsils for the presence of hemolytic streptococci were negative. In nine the skin test was positive, and hemolytic streptococci were found in the throat. In eight, the skin test was positive and no hemolytic streptococci were recovered. In the remaining two both examinations were negative. It was likewise found that the organisms might disappear from the throat without any change in the skin reaction. These

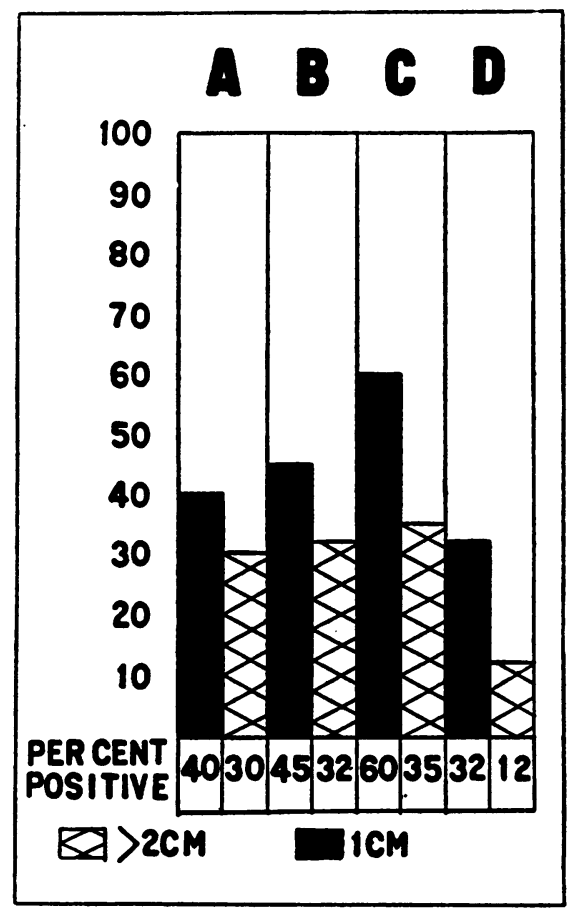

Fig. 3. The Size of the Skin Reactions to 0.01 mgm. OF NuClEOPROTEIN IN VARIOUS CONDITIONS

Group A represents cases of rheumatoid arthritis, Group B, cases of acute rheumatic fever, Group $C$, cases of acute respiratory infections associated with hemolytic streptococci, and Group D, a control group with a miscellany of conditions. The solid columns indicate the percentage of cases with a reaction of $1 \mathrm{~cm}$. or less than $2 \mathrm{~cm}$. in diameter and the hatched columns the percentage with the area of reaction greater than $2 \mathrm{~cm}$. in diameter.

observations indicate that the increased sensitiveness of the skin of patients may persist for long periods of time, and that skin reactions of great intensity in some of these patients are not necessarily dependent upon the presence of the organisms in the throat or upon the existence 
of a demonstrable infection in the body. Similar findings on the relationship between the presence of streptococci in the throat and the skin reactions to toxic filtrates of hemolytic streptococci have been made by Hansen-Pruss, Longcope, and O'Brien (2).

TABLE 2

Results of repeated skin tests with nucleoprotein

\begin{tabular}{|c|c|c|c|c|}
\hline \multirow{2}{*}{$\begin{array}{c}\text { Case } \\
\text { number }\end{array}$} & \multirow{2}{*}{$\begin{array}{c}\text { Months } \\
\text { of } \\
\text { obser- } \\
\text { vation }\end{array}$} & \multicolumn{3}{|c|}{ Size of reacting area } \\
\hline & & Nucleoprotein $0.01 \mathrm{mgm}$. & Nucleoprotein $0.001 \mathrm{mgm}$. & Nucleoprotein $0.0001 \mathrm{mgm}$. \\
\hline \multirow[t]{2}{*}{1} & 1 & $1.5 \stackrel{\mathrm{cm} .}{\times} 1.5$ & $1.5 \stackrel{c m .}{\times} \times 1.2$ & $\begin{array}{c}c m . \\
0\end{array}$ \\
\hline & $\begin{array}{l}1 \\
2\end{array}$ & $\begin{array}{l}1.5 \times 1.5 \\
1 \times 1\end{array}$ & $1.5 \times 1.2$ & 0 \\
\hline 2 & $\overline{1}$ & $1.8 \times 1.8$ & $1 \underset{0}{\times} 1$ & $\begin{array}{l}0 \\
0\end{array}$ \\
\hline \multirow[t]{2}{*}{3} & 1 & $2 \times 2$ & $1.5 \times 1.5$ & 0 \\
\hline & 2 & $1.2 \times 1.2$ & $1 \times 1$ & $\mathbf{0}$ \\
\hline \multirow[t]{2}{*}{4} & 1 & $1.5 \times 1.5$ & $1 \times 1$ & $\mathbf{0}$ \\
\hline & $\begin{array}{l}2 \\
3\end{array}$ & $\begin{array}{l}\mathbf{0} \\
\mathbf{0}\end{array}$ & $\begin{array}{l}\mathbf{0} \\
\mathbf{0}\end{array}$ & $\begin{array}{l}\mathbf{0} \\
\mathbf{0}\end{array}$ \\
\hline \multirow[t]{3}{*}{5} & 1 & $\mathbf{0}$ & $\mathbf{0}$ & 0 \\
\hline & 2 & $\mathbf{0}$ & $\mathbf{0}$ & $\mathbf{0}$ \\
\hline & 3 & $1 \times 1$ & $\mathbf{0}$ & $\mathbf{0}$ \\
\hline \multirow[t]{2}{*}{6} & 1 & $1.5 \times 1.5$ & $1.5 \times 1.5$ & $1 \times 1$ \\
\hline & $\begin{array}{l}2 \\
3\end{array}$ & $\begin{array}{l}1.5 \times 2 \\
1.2 \times 1\end{array}$ & $1 \underset{0}{\times} 1.5$ & $\begin{array}{l}0 \\
0\end{array}$ \\
\hline \multirow[t]{2}{*}{7} & 1 & $3 \times 3$ & $1.5 \times 1.5$ & 0 \\
\hline & 2 & $1 \times 1$ & $\mathbf{0}$ & $\mathbf{0}$ \\
\hline 8 & $\begin{array}{l}1 \\
2\end{array}$ & $\begin{array}{l}1.5 \times 1.5 \\
2 \times 2.5\end{array}$ & $\begin{array}{l}1.5 \times 1.5 \\
1.5 \times 1.5\end{array}$ & $1.5 \underset{0}{\times} 1.5$ \\
\hline \multirow[t]{2}{*}{9} & 1 & $1.5 \times 2$ & $1.5 \times 2$ & $1 \times 1.5$ \\
\hline & $\begin{array}{l}2 \\
3\end{array}$ & $\begin{array}{l}1.5 \times 2 \\
1.5 \times 2\end{array}$ & $\begin{array}{l}1.5 \times 1.5 \\
1 \times 1\end{array}$ & $\begin{array}{l}0 \\
0\end{array}$ \\
\hline \multirow[t]{2}{*}{10} & 1 & $2 \times 2$ & $1.5 \times 1.5$ & $1 \times 1$ \\
\hline & 2 & $1.8 \times 2$ & $1.5 \times 1$ & $\mathbf{0}$ \\
\hline \multirow[t]{4}{*}{11} & 1 & $3 \times 4.5$ & $2 \times 3$ & $\mathbf{0}$ \\
\hline & 2 & $3 \times 4$ & $2 \times 2$ & 0 \\
\hline & 3 & $1.6 \times 1.8$ & $\mathbf{0}$ & $\mathbf{0}$ \\
\hline & 4 & $3 \times 4$ & $2 \times 3$ & $\mathbf{0}$ \\
\hline \multirow[t]{4}{*}{12} & 1 & $1 \times 1$ & $\mathbf{0}$ & $\mathbf{0}$ \\
\hline & 2 & $1.2 \times 1.2$ & $1 \times 1$ & $\mathbf{0}$ \\
\hline & 3 & $1 \times 1$ & $1 \times 1$ & 0 \\
\hline & $\begin{array}{l}4 \\
5\end{array}$ & $\begin{array}{l}1.5 \times 1.5 \\
1 \times 1\end{array}$ & $\begin{array}{l}\mathbf{0} \\
\mathbf{0}\end{array}$ & $\begin{array}{l}\mathbf{0} \\
\mathbf{0}\end{array}$ \\
\hline \multirow[t]{4}{*}{13} & 1 & $2.5 \times 2$ & $1.5 \times 1$ & $\mathbf{0}$ \\
\hline & 2 & $2 \times 2$ & $1.5 \times 1.2$ & $1 \times 1$ \\
\hline & 3 & $2 \times 2$ & $1.5 \times 1.5$ & $\mathbf{0}$ \\
\hline & 4 & $1.5 \times 2.5$ & $\mathbf{0}$ & $\mathbf{0}$ \\
\hline
\end{tabular}


W. K. MYERS, C. S. KEEFER AND T. W. OPPEL

TABLE 2 (continued)

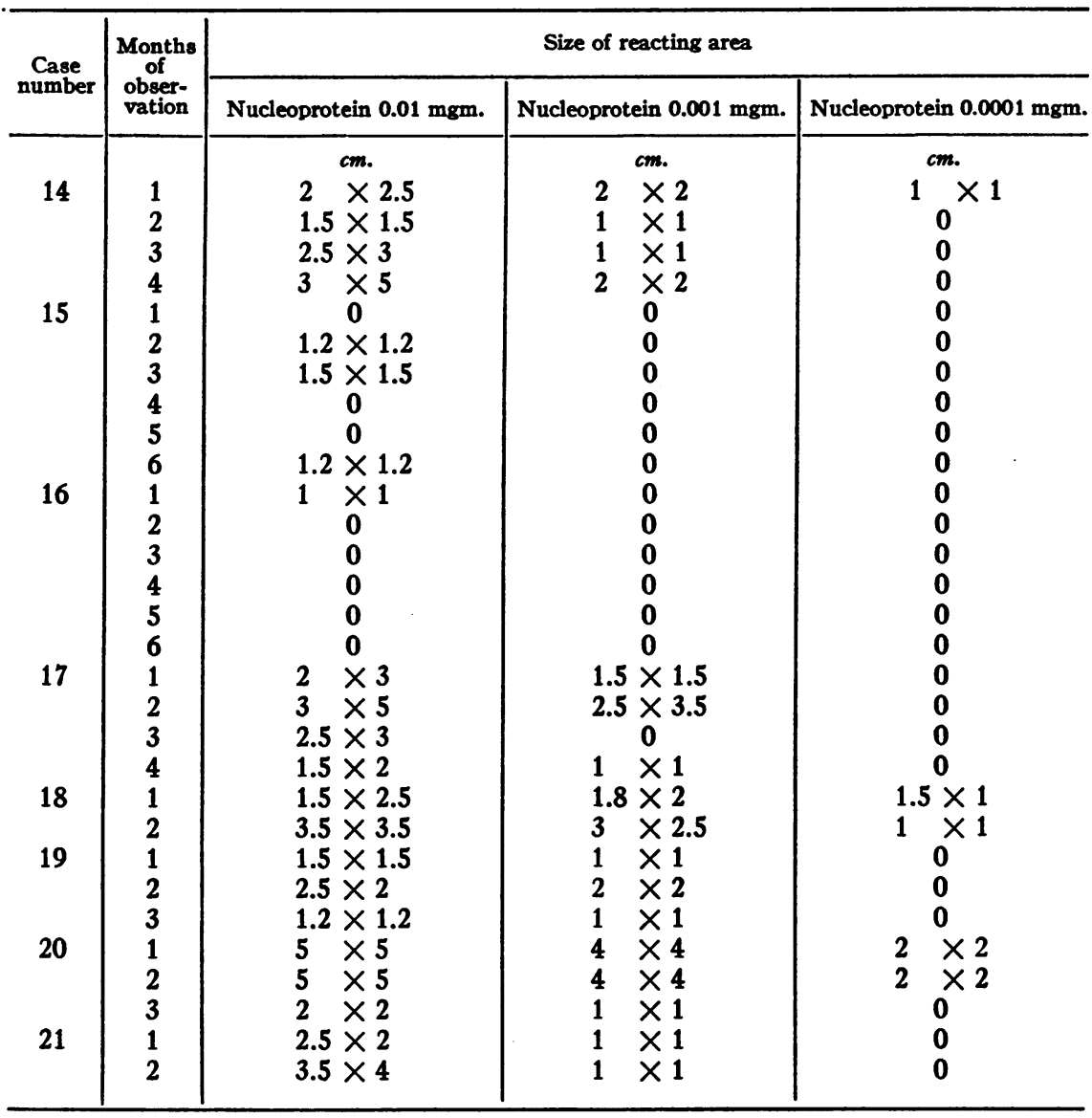

Relationship between skin reactions and agglutinins in the blood

The blood serum of all of the patients tested with nucleoprotein was examined for the presence of agglutinins, against the same organism from which the nucleoprotein was derived. The results are summarized in Table 3. It was common to observe a positive skin reaction and a negative agglutination test. In a number of cases both reactions were negative and in a few positive agglutination reactions were encountered in patients with negative skin reactions. In many instances when positive agglutinations were observed the skin reaction was also positive. It was brought out from these data that positive reactions may be observed without the presence of agglutinins in the blood, and agglutinins may sometimes be present without positive skin reactions. It seems clear, then, that the type of skin reactions that we followed were not dependent upon the presence of agglutinins in the circulating blood. 
TABLE 3

Relationship of skin tests to nucleoprotein and agglutination tests

\begin{tabular}{|c|c|c|c|c|c|c|c|}
\hline Disease & $\begin{array}{c}\text { Number } \\
\text { of } \\
\text { cases }\end{array}$ & $\begin{array}{c}\text { Number } \\
\text { of } \\
\text { skin } \\
\text { tests } \\
\text { positive }\end{array}$ & $\begin{array}{c}\text { Number } \\
\text { of } \\
\text { aggluti- } \\
\text { nation } \\
\text { tests } \\
\text { positive }\end{array}$ & $\begin{array}{l}\text { Number } \\
\text { of } \\
\text { skin } \\
\text { and } \\
\text { aggluti- } \\
\text { nation } \\
\text { tests } \\
\text { both } \\
\text { positive }\end{array}$ & $\begin{array}{l}\text { Number } \\
\text { of } \\
\text { skin } \\
\text { and } \\
\text { aggluti- } \\
\text { nation } \\
\text { tests } \\
\text { both } \\
\text { negative }\end{array}$ & $\begin{array}{l}\text { Number } \\
\text { of } \\
\text { skin } \\
\text { tests } \\
\text { positive, } \\
\text { aggluti- } \\
\text { nation } \\
\text { tests } \\
\text { negative }\end{array}$ & $\begin{array}{c}\text { Number } \\
\text { of } \\
\text { skin } \\
\text { tests } \\
\text { negative } \\
\text { aggluti- } \\
\text { nation } \\
\text { tests } \\
\text { positive }\end{array}$ \\
\hline 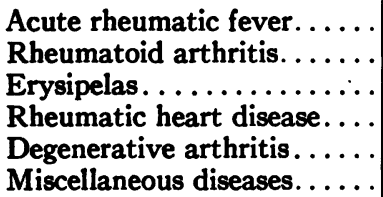 & $\begin{array}{r}39 \\
20 \\
15 \\
26 \\
23 \\
163\end{array}$ & $\begin{array}{r}31 \\
14 \\
8 \\
14 \\
7 \\
72\end{array}$ & $\begin{array}{r}9 \\
12 \\
4 \\
3 \\
4 \\
0\end{array}$ & $\begin{array}{l}7 \\
8 \\
3 \\
2 \\
1 \\
0\end{array}$ & $\begin{array}{r}6 \\
2 \\
6 \\
11 \\
13 \\
91\end{array}$ & $\begin{array}{r}24 \\
6 \\
5 \\
12 \\
6 \\
72\end{array}$ & $\begin{array}{l}2 \\
4 \\
1 \\
1 \\
3 \\
0\end{array}$ \\
\hline
\end{tabular}

\section{COMMENT}

In spite of the fact that there is always difficulty in comparing the results of various investigators, who have studied the skin reactions to products of the streptococcus, there seems to be general agreement about certain facts regardless of the substance used. In the first place, the type of reaction most commonly seen following the intradermal injection of a product derived from streptococci is the so-called "tuberculin" type of response, that is, the reaction reaches its maximum intensity within twenty-four to forty-eight hours, and gradually subsides in the following one or two days, sometimes leaving a pigmented area which desquamates after several days. An immediate wheal formation with an erythematous flare is much less frequent. The intensity of the reaction varies enormously in different individuals and depends upon a number of factors. In some instances red streaks appear in the lymphatics draining the area of skin infected, there is increased heat and tenderness at the site of the injection, and the lymph nodes in the axilla become moderately enlarged and tender. General reactions, with fever are unusual, but may be present.

One group of investigators has found that the skin reactions to streptococcal products are positive more often in rheumatic fever than in nonrheumatic controls (Birkhaug (3), Kaiser (4), Irvine-Jones (5), Swift, Wilson, and Todd (6), Coburn (7), Derick and Fulton (8)). HansenPruss, Longcope, and O'Brien (2) have found that patients with acute glomerular nephritis react to toxic filtrates of streptococci recovered from the nose or throat of these patients in a much higher percentage of cases than normal controls, or patients with streptococcal infection without nephritis.

MacKenzie and Hanger (9), on the other hand, were unable from their observations to correlate positive skin reactions with streptococcal infection or with any one disease or group of diseases. 
Coburn (7) found that the skin reactions fluctuated with the different time of year, increasing in frequency in New York between February and June, suggesting a direct relationship to the seasonal incidence of hemolytic streptococcal infections and contacts. Tonsillectomy did not alter the intensity of the reaction in children, and there was no relationship between the size of reaction and the severity of rheumatic fever in the cases he studied. Coburn interpreted the reactivity of the skin in rheumatic fever as an indication of a recent infection with the hemolytic streptococcus.

Another point noted by various observers (8) (10) seems evident, namely, that the number of positive skin reactions increases with age. This was also true in our cases.

From the data recorded above, certain facts seem obvious. The patients with rheumatoid arthritis, rheumatic fever, and respiratory infections associated with streptococcal infections showed positive reactions more often than the control group. They also showed more intense reactions, and responded more often to smaller amounts of the nucleoprotein. In spite of these observations there was no relationship between the size of the reaction and the severity of the disease from which the patient was suffering. Furthermore, there was no correlation between the presence of streptococcal agglutinins in the blood serum of these patients, and the positive skin reactions. This indicates that the two reactions are independent of each other. Finally, it was shown that positive skin reactions persist for a number of months and that they are not necessarily dependent upon the presence of organisms in the throat, or the existence of a demonstrable streptococcal infection in the body.

The question arises whether or not one is justified in assuming that the joint lesions in some of the patients with rheumatoid arthritis are the result, in part, of an allergic response to the products of the hemolytic streptococcus. Zinsser and Grinnell (11) have shown that hypersensitiveness of the joints may be produced with both pneumococci and streptococci and this hypersensitiveness is parallel to the skin hypersensitivity. Freiberg (12) likewise has produced hypersensitiveness of the joint tissues, and arthritis in rabbits, following sensitization to bacterial products of the dysentery bacillus.

The organisms, however, which have attracted most attention in regard to sensitization of joints are the various types of streptococci.

Faber (13), Swift and Boots (14), Zinsser (11) and other investigators have found that animals sensitized to streptococci from one source may react to streptococci from other sources, thus showing that the sensitization is not necessarily strain-specific. These observations have served as a working hypothesis for the study of such conditions in man as acute rheumatic fever, acute nonsuppurative arthritis following streptococcal infection, such as scarlet fever, and some cases of rheumatoid (atrophic) arthritis. 
The precise relationship between the joint lesions observed in some cases of rheumatoid (atrophic) arthritis and bacterial allergy is still a question requiring much study. At the present time the evidence that there is some relationship between the two processes is not conclusive.

The fact that some cases of rheumatoid arthritis begin or become worse following an acute streptococcal infection, and the fact that the removal of "foci of infection" may result in a reactivation of the arthritis, has led many investigators to correlate streptococcal infection with some cases of arthritis. Furthermore, the reactions in the joints which may be observed following the injection of streptococcal vaccines, or the injection of streptococcal nucleoprotein have been taken as evidence of hypersensitiveness of the joints to the products of the streptococcus. Finally the observations that many of these patients have streptococcal agglutinins in their blood serum, and show positive skin reactions to streptococcal nucleoprotein in a high percentage of cases may be of importance in showing some correlation between streptococcal infection and some cases of rheumatoid arthritis.

\section{SUMMARY AND CONCLUSIONS}

Skin reactions to the nucleoprotein of a strain of Streptococcus scarlatinae were studied in four groups of cases: (1) a control group with a variety of diseases; (2) patients with acute rheumatic fever; (3) patients with rheumatoid atrophic arthritis; (4) patients with acute respiratory infections associated with hemolytic streptococci.

In the control group of 207 cases 44 per cent gave a positive reaction, but in only 12 per cent of the cases was the reaction marked. Seventyseven per cent of the 40 patients with acute rheumatic fever responded with a positive test and 32 per cent of these reactions were marked. Of the 20 patients with rheumatoid (atrophic) arthritis 70 per cent gave positive reactions of which 32 per cent were marked. Of skin tests in the 20 patients with respiratory infections due to hemolytic streptococci 95 per cent were positive and 35 per cent were markedly positive.

The patients in the last three groups as a rule reacted positively to a smaller amount of the material than those of the control group.

There was no correlation between the positive skin tests and the presence of agglutinins in the blood serum. The positive skin reaction is regarded as an evidence of allergy to the nucleoprotein of the hemolytic streptococcus.

The presence of strongly positive reactions in many of the patients with rheumatic fever, rheumatoid (atrophic) arthritis and respiratory infections due to hemolytic streptococci indicates that these patients may be highly allergic to the products of the hemolytic streptococci. 
We are indebted to Dr. F. H. L. Taylor, Miss Eleanor Shea and Miss Marjorie Jewell for assistance in the preparation and nitrogen determinations of the nucleoprotein.

\section{BIBLIOGRAPHY}

1. Lancefield, R. C., J. Exper. Med., 1925, xlii, 377. The Immunological Relationships of Streptococcus Viridans and Certain of Its Chemical Fractions. 1. Serological Reactions Obtained with Antibacterial Sera.

2. Hansen-Pruss, O. C., Longcope, W. T., and O'Brien, D. P., J. Clin. Invest., 1929, vii, 543. Skin Reactions to Filtrates of Hemolytic Streptococci in Acute and Subacute Nephritis.

3. Birkhaug, K. E., J. Infect. Dis., 1927, xl, 549. Rheumatic Fever; Bacteriologic Studies of Non-methemoglobin-forming Streptococcus with Special Reference to Its Soluble Toxin Productions.

4. Kaiser, A. D., J. Infect. Dis., 1928, xlii, 25. Skin Reactions in Rheumatic Fever. (Birkhaug test) Studies in 801 Persons with the Toxic Filtrate Produced by the Non-methemoglobin-forming Streptococcus Isolated from Cases of Rheumatic Fever.

5. Irvine-Jones, E. I. M., Arch. Int. Med., 1928, xlii, 784. Skin Sensitivity of Rheumatic Subjects to Streptococcus Filtrates; Its Relationship to Rheumatic Fever.

6. Swift, H. F., Wilson, M. G., and Todd, E. W., Am. J. Dis. Child., 1929, xxxvii, 98. Skin Reactions of Patients with Rheumatic Fever to Toxic Filtrates of Streptococcus.

7. Coburn, A. F., The Factor of Infection in the Rheumatic State. Williams and Wilkins, Baltimore, 1931.

8. Derick, C. L., and Fulton, M. N., J. Clin. Invest., 1931, x, 121. Skin Reactions of Patients and Normal Individuals to Protein Extracts of Streptococci.

9. MacKenzie, G. M., and Hanger, F. M., Jr., J. Immunol., 1927, xiii, 41. Allergic Reactions to Streptococcus Antigens.

10. Ando, K., and Ozaki, K., J. Immunol., 1930, xviii, 267. Studies on the "Toxins" of Hemolytic Streptococci. V. The Dick Test and Allergic Skin Reactions to Streptococcus Nucleoproteins.

11. Zinsser, H., and Grinnell, F. B., J. Bact., 1927, xiv, 301. Further Studies on Bacterial Allergy. The Antigens Involved in Pneumococcus Allergy.

12. Freiberg, J. A., Arch. Surg., 1929, xviii, 645. Allergy as a Factor in the Production of Proliferative Arthritis.

13. Faber, H. K., J. Exper. Med., 1915, xxii, 615. Experimental Arthritis in the Rabbit. A Contribution to the Pathogeny of Arthritis in Rheumatic Fever.

14. Swift, H. F., and Boots, R. H., J. Exper. Med., 1923, xxxviii, 573. The Question of Sensitization of Joints with Non-Hemolytic Streptococci. 